\title{
Midwifery Practice
}

A research-based approach

Edited by

Jo Alexander, Valerie Levy

and Sarab Roch 
(C) Series: Jo Alexander, Valerie Levy \& Sarah Roch

(C) This volume: Communication in midwifery, Mavis Kirkham; Iron and vitamin supplementation during pregnancy,

Elsa Montgomery; Exercise and pregnancy, Gillian Halksworth; Fetal medicine, Joanne Whelton; The elderly primigravida, Louise Silverton; Couvade - the retaliation of marginalised fathers, Paul Summersgill; Safer motherhood - a midwifery challenge, Mary Kensington; Pain and the neonate, Valerie Fletcher; Workload measurement in midwifery, Jean Ball; Negligence litigation research and the practice of midwifery, Robert Dingwall.

All rights reserved. No reproduction, copy or transmission of this publication may be made without written permission.

No paragraph of this publication may be reproduced, copied or transmitted save with written permission or in accordance with the provisions of the Copyright, Designs and Patents Act 1988, or under the terms of any licence permitting limited copying issued by the Copyright Licensing Agency, 90 Tottenham Court Road, London W1P 9HE.

Any person who does any unauthorised act in relation to this publication may be liable to criminal prosecution and civil claims for damages.

First published 1993 by

THE MACMILLAN PRESS LTD

Houndmills, Basingstoke, Hampshire RG21 2XS

and London

Companies and representatives

throughout the world

ISBN 978-0-333-57617-5

ISBN 978-1-349-12936-2 (eBook)

DOI 10.1007/978-1-349-12936-2

A catalogue record for this book is available from the British Library

Typeset by Footnote Graphics, Warminster, Wiltshire 
Dedicated to

ANN STEWART

Midwifery Professional Officer and Adviser English National Board for Nursing, Midwifery and Health Visiting 1983-1991

In memory of an outstanding midwife who encouraged greatly the development of research-based practice in midwifery 


\section{Contents}

Other volumes in the Midwifery Practice series

Contributors to this volume viii

Foreword $\mathbf{x}$

Preface $\quad$ xi

1. Mavis Kirkham: Communication in midwifery 1

2. Elsa Montgomery: Iron and vitamin supplementation during $\begin{array}{ll}\text { pregnancy } & 20\end{array}$

3. Gillian Halksworth: Exercise and pregnancy 35

4. Joanne Whelton: Fetal medicine 55

5. Louise Silverton: The elderly primigravida 74

6. Paul Summersgill: Couvade - the retaliation of marginalised $\begin{array}{ll}\text { fathers } & 91\end{array}$

7. Mary Kensington: Safer motherhood - a midwifery challenge 110

8. Valerie Fletcher: Pain and the neonate 134

9. Jean A. Ball: Workload measurement in midwifery 154

10. Robert Dingwall: Negligence litigation research and the
practice of midwifery

Index to all four volumes in the series 185 


\section{Other volumes in the Midwifery Practice series}

- Volume 1 Antenatal care ISBN 0-333-51369-X (paperback) ISBN 0-333-53861-7 (hardcover)

1. Joyce Shorney: Preconception care: the embryo of health promotion

2. Rosemary Currell: The organisation of midwifery care

3. Rosemary C. Methven: The antenatal booking interview

4. Jo Alexander: Antenatal preparation of the breasts for breastfeeding

5. Moira Plant: Maternal alcohol and tobacco use during pregnancy

6. Tricia Murphy-Black: Antenatal education

7. Jean Proud: Ultrasound: the midwife's role

8. Margaret Adams and Joyce Prince: The psychology of pregnancy

9. Jane Spillman: Multiple births - parents' anxieties and the realities

- Volume 2 Intrapartum care ISBN 0-333-51370-3 (paperback) ISBN 0-333-53862-5 (hardcover)

1. Rona Campbell: The place of birth

2. Sheila Drayton: Midwifery care in the first stage of labour

3. Christine Henderson: Artificial rupture of the membranes

4. Judith Grant: Nutrition and hydration in labour

5. Alison M. Heywood and Elaine Ho: Pain relief in midwifery

6. Jennifer Sleep: Spontaneous delivery

7. Valerie Levy: The midwife's management of the third stage of labour

8. Carolyn Roth and Janette Brierley: HIV infection - a midwifery perspective

- Volume 3 Postnatal care ISBN 0-333-51371-1 (paperback)

ISBN 0-333-53863-3 (hardcover)

1. Jennifer Sleep: Postnatal perineal care

2. Sally Inch: Postnatal care of the breastfeeding mother 
Other volumes in the Midwifery Practice series • vii

3. Jenifer M. Holden: Emotional problems following childbirth

4. Ellena Salariya: Parental-infant attachment

5. Janet Rush: Care of the umbilical cord

6. Chris Whitby: Transitional care

7. Margaret Adams and Joyce Prince: Care of the grieving parent, with special reference to stillbirth

8. Rowan Nunnerley: Quality assurance in postnatal care

9. Marianne J. G. Mills: Teenage mothers 


\section{Contributors to this volume}

Jean A Ball MSc DipN RGN RM

Senior Teaching Fellow, Nuffield Institute for Health Services Studies, the University of Leeds

Jean Ball has written widely on aspects of nursing and midwifery management, especially topics relating to quality assurance and staffing levels. As well as her previous management posts, she was formerly Director of Research for North Lincolnshire Health Authority. She contributed the Foreword to Volume 3 in this series.

Robert Dingwall MA PhD

Professor and Head of the School of Social Studies, University of Nottingham Robert Dingwall is a sociologist who has worked in both medical and legal fields. Before his appointment to the University of Nottingham, he worked at the Universities of Aberdeen and Oxford on a variety of projects including studies of health visitor training, agency decision making in child abuse, the social history of nursing and midwifery and the impact of medical negligence litigation.

\section{Valerie Fletcher MSc RGN SCM HV}

Neonatal Midwife, Paediatric Department, Glasgow Royal Maternity Hospital

Valerie Fletcher is an experienced neonatal nurse and midwife whose own research has alerted her to potential problems in the way babies are perceived and treated in neonatal intensive care units.

\section{Gillian Halksworth BA(Hons) RGN RM}

Integrated Midwife, Taff Ely, Mid Glamorgan

Gillian Halksworth works as a team member, providing continuity of care for midwifery clients. Her brief currently includes teaching aquanatal classes. In 1991, she was awarded a scholarship which facilitated travelling abroad to observe midwifery services. She is currently studying for a masters degree and has a particular interest in social deprivation and pregnancy outcome. 
Mary Kensington BA RGN RM ADM

Formerly Midwifery Sister, Maternity Department, Odstock Hospital, Salisbury

Since writing this chapter, Mary Kensington has returned to her native New Zealand. Her previous work experience, in a number of different countries including Australia, Northern Canada and Thailand, has given her a global perspective on health issues and maternity care.

\section{Mavis J Kirkham PhD SRN SCM Cert Ed}

Principal Lecturer in Midwifery, De Montford University, Leicester

An internationally respected author, researcher and practitioner, Mavis Kirkham is well known for her work on midwives' communication skills. She lectures widely on reseach in midwifery.

\section{Elsa Monigomery BSc(Hons) RGN RM}

Midwife, Princess Anne Hospital, Southampton

Elsa Montgomery's current post, that of a staff midwife rotating through all departments, keeps her in touch with all aspects of 'grass roots' midwifery. She wrote this chapter while on maternity leave.

\section{Louise I Silverton BSc SRN SCM MSc MTD}

The Nightingale and Guy's College of Health, London

An experienced midwife teacher, Louise Silverton is currently Head of Maternal and Child Health. She has carried out research into breastfeeding, and has a particular interest in ethics relating to midwifery practice.

Paul R Summersgill BA(Hons) PGCE

Department of Nursing Studies, Faculty of Medicine, the University of Southampton

A sociologist by training, Paul Summersgill now lectures in his subject to midwives and nurses. His interest in the role of fathers in the childbearing process is personal as well as academic (as he is a father himself). He is currently working for his $\mathrm{PhD}$.

Joanne Whelton RN RM Dip Counselling Skills

Regional Co-ordinator, Confidential Enquiry into Stillbirths and Deaths in Infancy (CESDI)

Joanne Whelton is now based at the London Hospital Medical College at Queen Mary's, Westminster. She has studied the understanding and application of research (ENB course 870) and has written a number of articles focusing on the sensitive dilemmas arising from prenatal testing and fetal medicine. 


\section{Foreword}

I am delighted to write the foreword to a new volume in the series Midwifery Practice: a research-based approach. The success of the three previous volumes dealing with antenatal, intrapartum and postnatal care reflects the interest and enthusiasm that exists amongst midwives both about research itself and about its relevance to their everyday practice.

This volume has been written with a view to exploring various aspects of midwifery practice from the use of iron and vitamin supplements in pregnancy through to the management of pain in the neonate and then highlighting the challenges that exist for the midwife in ensuring that her practice stands up to research scrutiny. The 'Practice checks' incorporated into the chapters should ensure that research findings are applied to care and delivery.

The contributors also address some of the more complex issues that may be encountered by the midwife. The recent developments in the field of fetal medicine are explored with interest and the reader is encouraged to consider the less comfortable areas into which consideration of such advances inevitably lead. The psychological and ethical issues that will be faced by parents and midwives in these situations are highlighted as is the midwife's need to prepare herself for such challenges.

With a distinguished list of contributors and a firm pragmatic base this volume complements the previous books in the series and provides an excellent resource for midwives as they seek to develop their practice, set their standards and audit their performance.

Ann Stewart to whom this book has been dedicated spent her professional life in the pursuit of excellence in midwifery practice and education. This book serves as a fitting tribute to her.

Joan Greenwood

Nursing Officer, Midwifery and Maternity Services, Department of Health 


\section{Preface}

Since the publication of the first three volumes in this series, events have moved on apace. There has been a considerable increase in the scope of graduate education available for midwives, with the first MSc programmes in Midwifery Studies now in existence. Pre-registration midwifery courses now have to be validated at least to higher education diploma level and, following the UKCC decision in 1991, this will soon apply to all postregistration courses. These developments in higher education have probably sprung, at least in part, from an increasing recognition by the profession of the importance of underpinning practice with sound research and the resultant need for all midwives to be knowledgeable 'consumers' of research.

For those who venture to undertake research (who could be called research 'producers'), there is an increasing recognition of the need for specific preparation for this work, and the development of a diploma course in research methods is a welcome initiative. All 'products' have to be distributed and important advances have taken place in this field also. In 1990, the first of what are to be annual publications of MIRIAD (the Midwifery Research Database) took place. MIRIAD has made available a wealth of information about studies relevant to midwifery conducted in the United Kingdom, both completed and ongoing. It is produced by the Midwifery Research Initiative based at the National Perinatal Epidemiology Unit, Oxford, and is now distributed through the Royal College of Midwives. Another development facilitating the distribution of research information was the inauguration in 1991 of a new national 'Research in Midwifery Conference' which is also to become an annual event. The Midwives Information and Resource Service (MIDIRS), the Midwives, Research and Childbirth series of books and the Research and the Midwife Conference continue to make outstanding contributions to the dissemination of research information.

Despite these initiatives, research information is still not always easily accessible to midwives. Access to good library services may be difficult, particularly for midwives working at a distance from academic centres. Libraries are not always as well staffed as they might be and stocks of 
journals and other resources may be inadequate (Shepherd 1990). Searching the literature is always time consuming and photocopying often expensive.

This series is intended to help fill the vacuum which exists between the current state of research and the literature readily available to practitioners. The series offers midwives and student midwives a broad ranging survey and analysis of the research literature relating to central areas of clinical practice. We hope that it will also prove useful to childbearing women, their families and others involved with the maternity care services. The books do not intend to provide the comprehensive coverage of a definitive textbook; indeed their strength derives from the in-depth treatment of a selection of topics. The topic areas were chosen with care and authors (most, but not all, of whom are midwives) were approached who have particular research interest and expertise. On the basis of their critical appraisal of the literature, the authors make recommendations for clinical practice, and thus the predominant feature of these books is the link made between research and key areas of practice.

The chapters have a common structure, identical to that found in the three earlier volumes, and this is described below. We have been led to believe, from readers' and reviewers' comments, that the structure is useful and appropriate. Some knowledge of basic research terminology will prove useful but its lack should not discourage readers.

We owe a debt of gratitude to many people; most of all to our authors who have worked so painstakingly to produce their contributions, to our publishers and to the many practitioners and students who have made valuable comments on draft material. A most welcome development has been the invaluable part that Richenda Milton-Thompson has played as publisher's editor for this series. She joined our 'team' some way through the production of the first three volumes and has had a pivotal role in the preparation of this one. Her skill and quiet enthusiasm have greatly enhanced our enjoyment of this collaborative venture.

There is certainly no lack of potential material for this series. The recent House of Commons Health Committee Report (1992) endorsed the importance of midwifery research and also urged the Government to provide an unprecedented opportunity for midwives to regain their autonomy and provide holistic care for women and their families. The consequences of any changes in patterns of care resulting from this report, or indeed from other initiatives, will need careful investigation; the prospect of perhaps collating information from these studies in further volumes is an exciting one. 


\section{- Common structure of chapters}

In fulfilment of the aims of the series, each chapter follows a common structure:

1. The introduction offers a digest of the contents;

2. 'It is assumed that you are already aware of the following...' establishes the prerequisite knowledge and experience assumed of the reader;

3. The main body of the chapter reviews and analyses the most appropriate and important research literature currently available;

4. The 'Recommendations for clinical practice' offers suggestions for sound clinical practice based on the author's interpretation of the literature;

5. The 'Practice check' enables professionals to examine their own practice and the principles and policies influencing their work;

6. Bibliographic sources are covered under References (to research) and Suggestions for further reading.

\section{- References}

House of Commons Health Committee 1992 Report on the maternity services (Winterton Report). HMSO, London

Shepherd T 1990 Resourcing Project 2000 courses: the role of library and information services. Nursing Information Subgroup of the Library Association/RCN Library, London

\section{- Further reading on research}

The titles listed below are suggested for those who wish to further their knowledge and understanding of the principles of research.

Cormack DFS (ed) 1991 The research process in nursing, 2nd ed. Blackwell Scientific Publications, Oxford

Distance Learning Centre Packages (1988-1992) Research awareness: a programme for nurses, midwives and health visitors, Units 1-13. South Bank Polytechnic, London

Field PA, Morse JM 1985 Nursing research: the application of qualitative approaches. Croom Helm, London 
xiv - Preface

Hicks C 1990 Research and statistics: a practical introduction for nurses. Prentice Hall, Hemel Hempstead

Hockey L 1985 Nursing research - mistakes and misconceptions. Churchill Livingstone, Edinburgh 